\title{
Edpuzzle-Based Blended Learning Model for Mechanic Engineering Learning to Improve Student Critical Thinking Skills in Vocational Schools
}

\author{
Rahmat Fajar Asrofin ${ }^{1}$, Agus Efendi ${ }^{2}$, Deny Tri Ardianto ${ }^{3}$ \\ ${ }^{1}$ Post Graduate Student Educational Technology, ${ }^{2}$ The Faculty of Teacher Training and \\ Education, Sebelas Maret University \\ ${ }^{2}$ Universitas Sebelas Maret, Surakarta, Indonesia \\ 1rahmatfajar@student.uns.ac.id,2agusuns@yahoo.com³ denytri@staff.uns.ac.id
}

\begin{abstract}
This study aims to produce a syntax model and EdPuzzle-based blended learning device that is valid, active and effective to improve students' thinking skills in engineering mechanics. Including research and development (Research and Development), discusses the ADDIE development model, including Analysis, Design, Development, Implementation, Evaluation. Edpuzzle-based blended learning testing model in learning and critical thinking skills test of students is done in class X students of SMK Negeri 5 Surakarta. The trial design of this study used One Group Pretest-Posttest Design. The results showed that the average value of the RPP learning instrument worth $87.6 \%$, with very decent criteria, the value of the material worth of 80.8 with a very decent category, the value of the media instrument of $84.2 \%$ with a very decent category. Meanwhile, $86.5 \%$ with very decent criteria. The use of EdPuzzle-based blended learning models in limited trials of teachers and students get an average value of $82,90 \%$ with very practical category. Thus the EdPuzzle-based blended learning model is effective in improving students 'thinking skills indifference with the students' critical test results from 70 to 89. The results of this study indicate that the EdPuzzle-based blended learning model developed is following the correct, practical and effective.
\end{abstract}

Keywords: Blended Learning, Edpuzzle, Critical Thinking, vocational high school.

\section{INTRODUCTION}

The era of globalization has quite a wide impact in various aspects of life, including demands in the administration of education. One of the real challenges is that education should be able to produce competent human resources, known as 21 st-century competencies. 21 st Century competence is the main competency that must be possessed by students to be able to take part in real life in the 21 st century. [1]

The toughest challenge for the world of education in Indonesia, especially SMKs in the globalization era as contained in Presidential Instruction No. 9 of 2016 concerning SMK revitalization is to prepare Indonesian people who are smart, honest, superior, characterized, competitive, and have a national spirit. This is following the demands of competence in $21 \mathrm{st}$ century learning in the era of the industrial revolution 4.0. For students to have competitiveness, 21 st century life skills must be trained in schools, including making 
comparisons, making data analyzes, making conclusions, solving problems, and applying their knowledge to real or contextual life contexts (BSNP, 2018). If the 21 st century life skills are not provided in schools then they will not have enough competitiveness in facing the digitalisation era as it is today.

Facing challenges that are far greater than in the past, every teacher needs to develop effective competencies for better change. In the era of the internet has worldwide, in the field of education is a necessity and demand for teachers to be responsive to changes in the $21 \mathrm{st}$ century. As stated by Shaeffer, et al in "Global Agenda for Children" about 21st Century Learning as quoted by SP Robinson and K. Kay: For the world to survive and prosper in the century, people will need to learn more and learn differently. A child entering the new century will likely face more risks and uncertainties and will need to gain more knowledge and more master skills than any generation before ". [2] The statement shows that to face the 21 stcentury teachers are required to continue learning with different approaches and ways because they face different times.

One of the main components supporting development in various fields can be done through the use of ICT (Information and Communication Technology). In other words, the future development of the Indonesian nation will be very balanced if the provision of education with the use of ICT can be combined into an ingredient that can increase maturity in students so that they realize the purpose of learning (learning independence). Aspects that can be developed to improve students' critical thinking skills are through strengthening the Blended learning model, which is a learning model that combines conventional learning (face to face) with ICT-based learning. In line with research conducted by M.Alwan that the blended learning model has proven to be effective in improving students' achievement and thinking ability. [3]

The toughest challenge for the world of education in Indonesia, especially SMKs in the globalization era as contained in Presidential Instruction No. 9 of 2016 concerning SMK revitalization is to prepare Indonesian people who are smart, honest, superior, characterized, competitive, and have a national spirit. This is following the demands of competence in 21 stcentury learning in the era of the industrial revolution 4.0. For students to have competitiveness, 21 st-century life skills must be trained in schools, including making comparisons, making data analyzes, making conclusions, solving problems, and applying their knowledge to real or contextual life contexts (BSNP, 2018). If the 21st-century life skills are not provided in schools then they will not have enough competitiveness in facing the digitalization era as it is today. Vocational Schools are formal vocational educational institutions that produce graduates with vocational competencies. SMK graduates are expected to be able to work more independently compared to high school graduates.

The same problem occurs at SMK Negeri 5 Surakarta. Based on preliminary observations on 4 to 6 September 2018 class X study program design and building information, it is known that the achievement of learning outcomes has not been maximized, namely the learning enthusiasm of students which is still low. This is marked by the lack of student interest in learning, many students feel bored and not excited when the learning process takes place. If the student's enthusiasm for learning decreases it will result in a decrease in learning achievement. This can be seen from several factors including passive students in learning and the low ability of students to think critically in solving a problem. Indicators of student passivity can be seen in the learning process in class, there are still many students who do not pay attention to the teacher's explanation, some students are less enthusiastic to ask questions, answer questions spontaneously from the teacher, or provide responses to teacher questions. One of the abilities that is very important for students to have 
and develop is the ability to think critically. This capability is needed to solve everyday problems and problems in the future. This is because in the process of critical thinking students will analyze, rethink, or come up with new ideas. [4]

Stephan related that if critical thinking skills are not made as an indicator of the success of the education process, it will have an impact on students when they are at university education level. Learners often have difficulty in identifying a complex problem. The need for critical thinking skills possessed by students, causing learning to run smoothly. [5] Therefore, it is necessary to find alternatives for classical learning that can overcome these problems without eliminating the feeling of social bond between students and classmates and between students and teachers. In other words, learning is not only enough to do face-to-face classics as has been done so far.

So to overcome these challenges, one of the efforts made by the government in dealing with demands for rapid change at the local, national and regional and global levels is to improve the curriculum, namely the 2013 curriculum which emphasizes character, student activeness (student center) and innovation in the learning process with a scientific learning approach.

Based on the results of observations in the field shows that the learning process of Mechanical Mechanics in schools is less encouraging students to think critically. According to E Rita The learning process should require diverse and interesting learning models to increase students' motivation and critical thinking skills in the learning process. [6] Therefore, we need an approach that can stimulate students' critical thinking skills in learning Mechanical Engineering. One approach that can be used to improve students' critical thinking skills is the EdPuzzle-based blended learning model. According to Usman blended learning is a learning model that combines the application of traditional learning in the classroom with online learning that utilizes information technology. This learning model optimizes the integration of existing oral communication in face-to-face learning with written communication in online learning. [7] Furthermore Blended Learning is flexible learning. In the implementation process, with involvement and participation in the learning process, Blended Learning can increase students' sense of responsibility. Besides, based on research conducted by A.R Sari that Blended Learning learning strategies are proven to be successful in increasing Learning Independence, Critical Thinking, and learning achievement [8] because of the interaction in Blended Learning learning models creates a motive for students to compete in learning. Based on the description and facts above, this study aims to test the feasibility, practicality, and effectiveness of Blended Learning through Edpuzzle learning models to improve students' critical thinking skills.

\section{METHOD}

This research is included in research and development (Research and Development), namely research used to produce certain products (creations), and test the effectiveness of these products [9]. The intended product is Edpuzzle-based Blended Learning in learning Mechanical Engineering to improve students' critical thinking skills. The EdPuzzle-based Blended Learning learning model developed in this study refers to the ADDIE development model covering the stages of Analysis, Design, Development, Implementation, Evaluation [10].

Edpuzzle-based Blended Learning model products developed were validated by a team of experts. Validation data from experts was analyzed qualitatively as input to improve the product being developed. Questionnaire data regarding expert responses regarding the 
feasibility of development products were analyzed by transforming the average score of all observed aspects into qualitative sentences with the criteria as in Table 1 [11]

Table 1. Criteria for eligibility of Edpuzzle-based Blended Learning models

\begin{tabular}{cc} 
Earnings Scale & Category \\
\hline $80-100$ & Very decent \\
$66-79$ & Worthy \\
$56-65$ & Decent enough \\
$40-55$ & Inadequate \\
$30-39$ & Not feasible
\end{tabular}

Analysis of critical thinking skills data is divided into two parts, namely analysis of critical thinking skills on each indicator and analysis of critical thinking skills as a whole. The categories of critical thinking assessment areas in the table below

Table 2. Categories of assessment of critical thinking [12]

Earnigs Scale Category

\begin{tabular}{cc}
\hline$>81,25-\leq 100$ & Very critical \\
\hline$>62,50-\leq 81,25$ & Critical \\
$>43,75-\leq 62,50$ & Less critical \\
\hline$\leq 25,00-\leq 43,75$ & Very less critical \\
\hline
\end{tabular}

\section{RESULT AND DISCUSSION}

The product validation of the development results in the form of Edpuzzle-based Blended Learning is carried out by four experts who are competent in their fields. The results of expert validation obtained are listed in Table 3.

\subsection{Results of Analysis Phase}

The analysis phase is the initial stage in developing Edpuzzle-based Blended Learning. At this stage, several activities were carried out, namely the analysis of the problems and needs of students and the analysis of Basic Competence. Problem analysis is done to determine the basic problems in the development of Edpuzzle-based Blended Learning. In this step, researchers, in general, observe the problems that arise in learning Mechanical Engineering class X at SMK Negeri 5 Surakarta. Analysis of students' needs, namely students needing innovations in learning Mechanical Engineering that can explain the content of materials composing parallel styles, this innovation as a researcher's offer is with EdPuzzle-based blended learning models in which abstract mechanical engineering materials can be explained by component models EdPuzzle based blended learning consisting of, ebook images, animation, and video learning. Basic competency analysis is determined that the material developed focuses on Basic Competence (3.4. Identifying equivalent styles. 4.4. Calculating equal styles).

\subsection{Planning Phase Results}

This stage is a systematic process that begins by formulating (1) the objectives including the formulation of learning objectives considering three learning domains that include cognitive domains that emphasize levels of thinking, affective domains that refer to 
attitudes and feelings and psychomotor domains that emphasize actions and skills. (2) formulating an evaluation tool, identifying learning objectives, compiling a specification table or grid, and determining the form of tests to be used. Tests designed in this study both in print and in the form of online tests. (3) determine learning strategies, delivery strategies used are a combination of face-to-face delivery and E-learning. The approach used is the 2013 curriculum recommended approach which is a scientific approach. And (4) determine learning material, selected learning material is to arrange parallel styles. The selection is based on (1) the results of discussions with several video expertise package educators, and (2) consider the time of conducting the research.

\subsection{Results of Development Phase}

This stage is the stage of developing EdPuzzle based blended learning prototypes

\subsubsection{Validation Result}

Product validation resulting from the development of Edpuzzle-based Blended Learning is carried out by experts who are competent in their fields. RPP validation assessment indicators are carried out based on aspects of the format, aspects of content and aspects, indicators of model validation assessment are based on aspects of syntax, social systems, reaction principles, support systems, learning impacts and the impact of accompaniment and learning implementation. While the material validator is based on two aspects, namely Content Usefulness, Content Adequacy and EdPuzzle media validator based on Functionality, Accessibility Interactivity, Easy of use, Easy of use, Interface design (Display interface), Availability (availability when needed) Personalization (Personality). The results of expert validation obtained are listed in Table 3.

Table 3. Expert Validation Results

\begin{tabular}{lccc}
\hline No & Validator & Average (\%) & Criteria \\
\hline $\mathbf{1}$ & Learning Implementation Plan (RPP) & 87,6 & Very decent \\
\hline $\mathbf{2}$ & Syntax Blended Learning (Edpuzzle) & 89,9 & Very decent \\
\hline $\mathbf{3}$ & Theory & 80,8 & Very decent \\
\hline $\mathbf{4}$ & Media & 84,2 & Very decent \\
\hline $\mathbf{5}$ & Critical Thinking Instrument & 86,5 & Very decent \\
\hline
\end{tabular}

Source: Expert Validation Results

Based on Table 3 shows that the average percentage of the results of the validation/feasibility of the Learning Implementation Plan (RPP) $87.6 \%$ with very decent criteria, while Syntax Blended Learning (Edpuzzle) $89.9 \%$ with very decent criteria, Material with 80.8 criteria \% with very reasonable criteria, the results of media validation of $84.2 \%$ with the criteria very feasible and Critical Thinking Instruments with a criteria of $90.5 \%$ are very feasible so that EdPuzze-based blended learning models and instruments of critical thinking skills can be implemented in learning.

\subsection{Results of Implementation Phase}

This stage is the stage of EdPuzze-based blended learning model implemented in class X students of SMK Negeri 5 Surakarta with limited trials of small groups, large groups, and large scale.

\subsubsection{Limited Trial Results}


Limited trials of small groups and large groups were conducted to learn the practicality and legibility of the product developed. This trial was conducted by teachers and students who represented the EdPuzzle-based mixture of blended learning user models that were developed. The results of the practicality of the EdPuzze-based blended learning model of student teachers are listed in Table 4.

Table 4. Limited Trial Results

\begin{tabular}{ccc} 
Respondent & $\begin{array}{c}\text { Average } \\
\mathbf{( \% )}\end{array}$ & Criteria \\
\hline Teacher & $80,6 \%$ & Very Practical \\
\hline Student & $85,2 \%$ & Very Practical \\
\hline Average & $82,90 \%$ & Very Practical \\
\hline
\end{tabular}

\subsubsection{Broad Class Trial Results}

Based on data obtained from the final test (post-test), it is known that the students' critical thinking skills before and after being taught with EdPuzzle-based blended learning models have significant differences. Edpuzzle-based blended learning models proved to be significant in improving students' critical thinking skills. Students' critical thinking skills before they are applied (pretest) and after they are implemented (Posttest) EdPuzzle-based blended learning models have better critical thinking abilities than before the implementation of EdPuzzle-based blended learning models. This is in line with research conducted by Wiwik\& et al. That there are significant differences in the critical thinking skills of the experimental class students and the control class significantly. This means that the application of blended learning has a significant influence on students' critical thinking abilities. [13] further the results of research I. N. J. Luh Rika Sukayanti, \& et al that blended learning is effective in improving student learning outcomes [14]. Thus blended learning becomes the most appropriate solution for the learning process that is suitable, not only with the learning needs but the learning style. A blended le arning atmosphere will require students to play a more active role in learning.

\subsection{Results of the Evaluation Phase}

After going through the previous stages, the development of the Edpuzzlebased blended learning model gets some improvements that must be done. Evaluation of the Edpuzzle-based blended learning model is based on an assessment sheet, input, and suggestions from expert validators and test subjects as users. The evaluation phase is carried out with two parts, namely formative and summative evaluation. Formative evaluations are carried out at each stage of the development of ADDIE. Whereas summative evaluation consists of the final evaluation of the whol [15].

\section{CONCLUSION}

Based on the results of data analysis and discussion, it can be concluded that the Edpuzzle-based blended learning model is feasible to use, the use of the Edpuzzle-based blended learning model in limited trials gets responses from teachers and students in a very practical category. Edpuzzle-based blended learning models 
are effective for improving students' critical thinking skills. This is indicated by the differences in the results of the students' pretest and posttest critical thinking skills. The average score of students' critical thinking skills before applying the Edpuzzlebased blended learning model is 70.00 with the less critical category. While the average score of students' critical thinking after applying EdPuzzle-based blended learning media model is 89.00 with a very critical category. Then it can be concluded that the Edpuzzle-based blended learning model is feasible, practical and effective can improve students' critical thinking skills in learning mechanical engineering. Thus this blended learning model is proven to be able to accommodate students' learning interests so that they can improve their critical thinking skills through problem-solving by each student. Therefore teachers are advised to be able to develop creative learning models to motivate students' learning.

\section{REFERENCES}

[1] E. Y. Wijaya, D. A. Sudjimat, and A. Nyoto, "Transformasi Pendidikan Abad 21 Sebagai Tuntutan Pengembangan Sumber Daya Manusia di Era Global," J. Pendidik., 2016.

[2] S. P. Robinson and K. Kay, "21St Century Knowledge and Skills In Educator Preparation," The American Association Teacher of Educator \& The Partnership for 21st Century Skill. 2010.

[3] M. Alwan, "Pengembangan model blended learning menggunakan aplikasi Edmodo untuk mata pelajaran geografi SMA," J. Inov. Teknol. Pendidik., 2017.

[4] E. Prihartini, P. Lestari, and S. A. Saputri, "Meningkatkan Kemampuan Berpikir Kritis Matematis Menggunakan Pendekatan Open Ended," Pros. Semin. Nas. Mat. IX 2015, 2016.

[5] M. Rahmi Stephani, A. Suherman, and R. B. Mulyana, "Pengaruh Model Pembelajaran Inkuiri Terhadap Kemampuan Berpikir Kritis Dan Keterampilan Bermain Bola Basket," Edusentris, vol. 1, no. 2, p. 156, 2014.

[6] E. Erita, "Pengaruh Model Pembelajaran," Economica, 2017.

[7] U. Usman,"Komunikasi Pendidikan Berbasis Blended Learning Dalam Membentuk Kemandirian Belajar," j. Jurnalisa, 2019.

[8] A. R. Sari, "Strategi Blended Learning Untuk Peningkatan Kemandirian Belajar Dan Kemampuan Critical Thinking Mahasiswa Di Era DigitaL," J. Pendidik. Akunt. Indones., 2013.

[9] Sugyono, Metode Penelitian Kuantitatif,Kualitatif, R\&D. Bandung: Alfabeta, 2018.

[10] O. Dick, W., Carey, L., \& Carey, J, The Systematic Design Of Intruction. Universitas Of South Florida: Emeritus, 2009.

[11] T. (2017). Ernawati, I., dan Sukardiyono, "Uji Kelayakan Media Interaktif Pada Mata Pelajaran Administasi Server.," J. Elinfo (Electronics, Informatics Vocat. Educ., vol. 2, no. 2, 2017.

[12] S. H. Muhammad Shohibul Ihsan1, Agus Ramdani2, "E-Learning Development In Chemitry Learning To Improve The Student Critical Thinking Ability," J. Pijar MIPA, vol. 14, no. 2, pp. 84-87, 2019.

[13] W. S. Ambar Ningsih, W. Suana, and N. Maharta, "Pengaruh Penerapan Blended Learning Berbasis Schoology Terhadap Kemampuan Berpikir Kritis Siswa," Konstan - J. Fis. DAN Pendidik. Fis., 2018.

[14] I. N. J. Luh Rika Sukayanti, I Komang Sudarma, "Pengembangan blended learning tipe flipped class room pada mata pelajaran seni budaya kelas XI," J. Jur. Teknol. 
Pendidik., 2018.

[15] A.J. Harahap, E. Ongko, H. Manurung, D. Kurnia, H. Hartono, D. Abdullah, K. Saddhono, and C.I Erliana "Sylabus and Matrials Design for Vocational Student and Its Dissemination Using Website." In IOP Journal of Physics: Conference Series, vol. 1114 no. 1, p. 012023. IOP Publishing, 2018. 